\title{
AyURLOG
}

National Journal of Research in Ayurved Science

\section{Literature Review of Brahmacharya as Pathway for healthy living.}

\section{Ganesh S. Puradkar ${ }^{1}$, Saurabh Ravindra Shirishkar*2, Sujay Randive ${ }^{3}$}

1. Associate Professor, Samhita \& Siddhant Department, Ayurved Mahavidyalaya, Sion, Mumbai, Maharashtra.

2. PG Scholar, Samhita \& Siddhant Department, Ayurved Mahavidyalaya, Sion, Mumbai, Maharashtra.

3. Reader, Department Of Samhita, Bhagwant Ayurvedic College \& Bhagwant Hospital, Muzaffarnagar (U.P.)

*Corresponding author: shirishkarsaurabh@ gmail.com

\section{ABSTRACT}

Ayurved is science of life, having aims to live healthy life and cure diseases. In Ayurved, concept of Trayoupstambha is mentioned which leads to healthy life. Trayoupstambha means three sub pillars which gives healthy life. Out of these three sub pillars 'Brahmacharya' is one, which assists healthy living being. Brahmacharya results in conservation of Shukra Dhatu \& Shukra Dhatu is essence of Ahara. Shukra Dhatu is responsible for Bala, Virya, Yasha, Dhairya, Preeti. Hence these qualities ultimately lead to healthy life. Physical \& mental health is achieved through Brahmacharya. So, this is literature study to review Brahmacharya concept, its various parameters \& its significant role in healthy living.

Keywords: Ayurved, Brahmacharya, Trayoupastambha, Shukra Dhatu. INTRODUCTION
In Ayurved, there are various principles related to different aspects of life which gives direction to be healthy and free from disease throughout the life. 'Trayo upastambha' is one of those principles. According to Charaka 'Tridanda' means Mana, Aatma, Sharir are main pillars of life \& According to Sushrut 'Tristhuna' means Vata, Pitta, Kapha are main pillars of life. So, these two will be supported by Trayoupstambha which are Aahar, Nidra \& Brahmacharya. Brahmacharya is made up of two components which are 'Brahma' \& 'Charya'. 'Brahma' means the absolute, eternal truth, ultimate reality \& supreme God-head. 'Charya' means 'to follow'. So Brahmacharya means the virtuous way of lifestyle or way of behaviour to achieve ultimate reality, eventually which leads to healthy living. Brahmacharya indirectly helps to other two upastambha to protect life. Hence, major importance is given to Brahmacharya. 


\section{AIM \& OBJECTIVES}

1. To review literature of Brahmacharya concept.

2. To emphasize its role in healthy living. REVIEW OF LITERATURE

Brahmacharya phenomenon given in many Samhitas like Charak Samhita, Sushrut Samhita, Ashtang Hridaya, Yadnyavalkyasmruti etc. In Charak Samhita, $11^{\text {th }}$ chapter called 'Tisreshaniya Adhyay' which comes under 'Nirdesh Chatushka' (group of 7 chapters) of Sutrasthana gives knowledge about Brahmacharya. In this chapter, to achieve Trividha Eshanas (3 wishes) of life 7 Trikas (Triads) are explained ${ }^{(1)}$. Out of these 7 Trikas one is Trayoupastambha. Trayoupastambha consists of two components 'Traya' which means three in numbers \& 'Upastambha' which means sub pillars. These Trayoupastambha are Ahara, Nidra \& Brahmacharya. If these three are maintained in regulated manner through Yukti (proper management) they act as sub pillars by providing strength, complexion till the end of life, its necessary that a person does not indulge in any activities which are harmful to health ${ }^{(2)}$.

Acharya Charak has mentioned that Brahmacharya is most superior in providers of best life. Hence eventually Brahmacharya improves quality of life (3). Sushrut in Sushrut Samhita Chikitsa Sthan mentioned that Brahmmacharya if follows properly it leads to improvement of $A y u$ (life) (4). Acharya Vagbhat in Ashtang Hriday Sutrasthan mentioned similarly that if Ahara, Nidra \& Brahmacharya maintained in proper regulated manner as mentioned in Shastra they act as strong pillars for healthy life like strong pillars hold house ${ }^{(5)}$.

\section{Brahmacharya Definition:}

- Chakrapani has stated that Brahmacharya means control over Indriyas with purity of Mana to achieve
Brahma Dnyan. It's very important that this control should be done very tactfully because over control, less or no control leads to Manasik Kshobha ${ }^{(6)}$.

- Brahmacharya is not always abstinence from Maithun karma, it also includes practicing Maithun Karma with disciplines or regulations as mentioned in Rutukala considered as Brahmacharya (7)

- It is also stated that Brahmacharya is path to achieve Moksha, one such path is by keeping in check activities of Karmendriya such as Upastha which helps in maintaining life span is Brahmacharya $^{(8)}$.

- Acharya Sushrut has mentioned that regulated control over all Indriya is Brahmacharya $^{(9)}$.

- Brahmacharya is one of five Yamas which is mentioned under Raksha vidhan in Vrana Chikitsa of Sushrut Chikitsa Sthan ${ }^{(10) .}$

- Acharya Charak has mentioned Brahmacharya in Aachar Rasayan. The person who follows Brahmacharya he doesn't need to get any other Rasayan externally because he gets benefits of Rasayan Karma by following Brahmacharya $^{(11)}$.

\section{Attributes of Brahmacharya:}

In Vaidyakiya Subhashit Sahityam, Brahmacharya classified into 1) Naishthik Brahmacharya \& 2) Vaivahika Brahmacharya. Also classified as Ashtang Brahmcharya.

Naishthika Brahmacharya - It can be defined as controlled \& regulated activities of Sharir, Mana \& Vak (speech) throughout the life since birth till end of life ${ }^{(12)}$.

Vaivahika Brahmacharya - The person who even in gruhastha follows the disciplines, rules for the intention of Pitru Runa Mukti (13)

Ashtang Brahmacharya - It is controlled \& regulated activities of Shrotradi \& Mana 
while they come in contact with their Arthas like Shabdadi ${ }^{(14)}$.

In Yadnya Valkya Smriti eight types of Maithuna Karma has been explained which are as follows: 1. Smarana (Memorising of female by male \& vice versa) 2. Kirtan (Talking about each other's qualities) 3. Keli (to indulge in play) 4. Prekshan (looking with sexual urge) 5. Guhyabhashan (Talking in lonely place) 6 . Sankalpa (To prepare for coitus) 7. Adhyavasaya (To attempt or effort) 8. Kriya (Coitus or Sexual intercourse). Only sexual intercourse is not defined as Maithuna. These all are considered as Maithuna. So, to control all these is defined as Brahmacharya $^{(15)}$.

\section{Abrahmacharya -}

Acharya Vagbhat has mentioned Abrahmacharya while Acharya Charak has mentioned Brahmacharya. Brahmacharya \& Abrahmcharya stands for same. The only difference is Abrahmacharya is practicing tactfully \& disciplined Maithuna Karma in Gruhasthashram according to Acharya Vagbhat ${ }^{(16)}$. Gruhasthashram is only phase of life in which controlled \& disciplined Maithuna Karma is advised. In Ashtang Hriday, it is advised for both men \& women that a male should not indulge in sexual intercourse with a female who is not free from bleeding phase of menstrual cycle, who is not wishing for sexual intercourse, whose behaviour is not favourable, who is free from sexually transmitted diseases, who is very skinny or obese, who is recently delivered a baby (Postpartum period) or who is pregnant or who is not your wife or who is from other religion or caste \& vice versa (whichever is applicable for males) ${ }^{(17)}$.

It is also advised that Maithuna Karma should not be done at Guru's place like Gurukul, Holy places like temples, Respected places like heritage, Places of Hawan, Burial sites, Places near river etc. It is also advised that Maithuna Karma should be avoided on day of Sankranti, Solar or Lunar eclipse day, A full moon day (Pournima) or No moon day (Amavasya) ${ }^{(18)}$.

It is mentioned that a person who had taken excess of food, who is in anxiety, who is hungry, who is not in proper position, who is thirsty, who is not adult yet or who is in old age, who is in urge of passing urine or stool should not indulge in Maithuna Karma (19)

It is advised that a person (male or female) who had taken medicines to improve virility (Vajikaran) should practice Maithuna Karma According to wish in Winter Season i. e. Hemant or Shishir Ritu, with gap of 3 days in Vasant (Spring) \& Sharad (Autumn) Ritu \& with gap of 15 days in Grishma (summer) \& Varsha (Rainy) seasons ${ }^{(20)}$.

It is also advised that after Maithuna Karma a person should take bath \& clean sexual organs properly. A person should anoint with Chandan, Kasturi Lepa \& should take milk, sweets, soup in diet according to season ${ }^{(21)}$.

\section{DISCUSSION}

\section{Importance of Trayoupastambha:}

Acharya Charak has mentioned Aahar (Proper food), Nidra (Proper sleep) \& Brahmcharya as Trayoupastambha. These 3 are sub pillars which holds life if all of these three are in proper manner. In detail if we see Acharya Charak has considered Tridanda as main Stambha (pillars) of life. These are Satwa, Aatma \& Sharir. These three supports life \& Trayoupastambha supports these Tridanda to protect Ayu (life). It's very important that each of these three Aahar, Nidra \& Brahmacharya should be maintained properly. Any one of Upastambha if not maintained properly eventually its imbalances other two Upastambha even if they are maintained properly. Hence each Upastambha should be in regulated manner to achieve healthy life. In regulated maintenance of 
Trayoupastambha it should be done through Yukti i.e., through proper management.

Brahmacharya \& Maithuna Karma:

Brahmacharya is not always abstinence from Maithuna Karma. Brahmacharya also means practicing Maithuna Karma in disciplined manner as mentioned in Rutukal \& as mentioned in Shatsra. In Rutucharya we have references about practicing Maithuna Karma according to seasonal variations. As we have seen references regarding to do \& not to do while practicing Maithuna Karma. So, practicing Brahmacharya means completely avoiding Maithuna Karma is myth. At the same time, we should have controlled activities of our Indriya (sensory organs).

\section{Brahmacharya \& Rasayan Karma:}

Shukra Dhatu is made from essence of Aahar. Shukra dhatu is responsible for strength, complexion of body \& Oja which ultimately gives Deerghayu (long life), Aarogya(health), Smriti (memorising power), Prabha (Lustre), Varna (Complexion), Sharir Bala (strength to body), Indriya Bala (strength to sensory organs). These all are benefits of Rasayan Karma. Brahmacharya helps in conservation of Shukra Dhatu. So eventually Brahmacharya gives benefits of Rasayan Karma. In Achar Rasayan Acharya Charak has mentioned about Brahmacharya.

\section{Conclusion:}

Trayoupastambha is a tool to achieve Trividha Eshanas of life. Trayo upastambha helps to keep life in healthy status. Many diseases are caused due to improper management of Trayoupastambha. Hence Brahmacharya is responsible for healthy life. Brahmacharya is nothing but regulated activities of Indriya throughout the life \& disciplined practice of Maithuna Karma in Gruhasthashram with intention of Pitru Runa Mukti. So, considering all above discussions we can conclude that Brahmacharya is way of healthy living.

\section{References:}

1. Dr. Tripathi Bramhanand, Charaka Samhita, Re- Edition, Chaukhamba Surbharati Prakashan, 2006, Varanasi, P-238.

2. Ibid Dr. Tripathi Bramhanand, Charaka Samhita, P-238.

3. Ibid Dr. Tripathi Bramhanand, Charaka Samhita, P-459.

4. Dr. Thakaral Keval Krishna, Sushrut Samhita with Nibandha Sangraha Commentary of Acharya Dalhan, ReEdition, Chaukhambha Orientalia, 2016, Varanasi, P- 456.

5. Dr. Tripathi Bramhanand, Ashtang Hridayam of Shrimad Vagbhat, ReEdition, Chaukhamba Sanskrit Pratishtan, 2012, Varanasi, P-129.

6. Vd. Kushwaha Harishchandra Singh, Charak Samhita with Ayurved dipika Commentary of Shri Chakrapani, ReEdition, Chaukhambha Orientalia, 2009, Varanasi, P- 171.

7. Dr. Dwivedi Lakshmidhar, Maharshi Agnivesh Pranit Charak Samhita with Ayurved dipika Commentary of Shri onakrapani, $3^{\text {rd }}$ Edition, Chaukhamba Krishnadas Academy, 2020, Varanasi, P- 59.

8. Ibid Vd. Kushwaha Harishchandra Singh, Charak Samhita, P- 136.

9. Ibid Dr. Thakaral Keval Krishna, Sushrut Samhita, P-28.

10. Dr. Thakaral Keval Krishna, Sushrut Samhita with Nibandha Sangraha Commentary of Acharya Dalhan, $1^{\text {st }}$ Edition, Chaukhambha Orientalia, 2014, Varanasi, P-196.

11. Dr. Dwivedi Lakshmidhar, Maharshi Agnivesh Pranit Charak Samhita with Ayurved dipika Commentary of Shri Chakrapani, $3^{\text {rd }}$ Edition, Chaukhamba Krishnadas Academy, 2020, Varanasi, P-53.

12. Bhaskara GG., Vaidyakiya Subhashita Sahityam, Chapter $21,7^{\text {th }}$ 
Edition, Chaukhamba Sanskrit Sansthan, 1999, P-130.

13. Ibid Bhaskara GG., Vaidyakiya Subhashita Sahityam, P-130.

14. Ibid Bhaskara GG., Vaidyakiya Subhashita Sahityam, P-130.

15. Dr Bhakara Govind Ghanekar, Vaidyakiya Subhashit Sahityam, Chaukhambha Prakashan, Reprinted 2016, P-131.

16. Dr. Tripathi Bramhanand, Ashtang Hridayam of Shrimad Vagbhat, Re-
Edition, Chaukhamba Sanskrit Pratishtan, 2012, Varanasi, P-129.

17. Ibid Dr. Tripathi Bramhanand, Ashtang Hridayam, P-132.

18. Ibid Dr. Tripathi Bramhanand, Ashtang Hridayam, P-132.

19. Ibid Dr. Tripathi Bramhanand, Ashtang Hridayam, P-132.

20. Ibid Dr. Tripathi Bramhanand, Ashtang Hridayam, P-133.

21. Ibid Dr. Tripathi Bramhanand, Ashtang Hridayam, P-134.

Cite this article:

Shirishkar, S. (2021). Literature Review of Brahmacharya as Pathway for Healthy Living.

Ayurlog: National Journal of Research in Ayurved Science, 9(02).

https://doi.org/10.52482/avurlog.v9i02.839

Ayurlog: National Journal of Research in Ayurved Science- 2021; (09) (02):01- 05 